\title{
ROLA KOŚCIOŁA KATOLICKIEGO W PROCESIE WYCHOWYWANIA DZIECI I MLODZIEŻY DO PRACY CHARYTATYWNEJ I WOLONTARIATU
}

\section{Wstęp}

Człowiek jest istotą społeczną. Obdarzony różnymi charyzmatami, na każdym etapie swojego życia, wspiera budowanie społeczeństwa sprawiedliwego i obywatelskiego, gdzie uprzywilejowaną rolę zawsze powinny zajmować osoby słabe i potrzebujące pomocy. Kościół katolicki od samego początku swojego istnienia stawia w centrum swojej posługi, obok nauczania, głoszenia Słowa Bożego, sprawowania sakramentów, posługę na rzecz potrzebujących oraz wychowywanie członków Kościoła do posługi wobec nich ${ }^{1}$. Tym samym dzieła miłosierdzia wpisują się w istotny nurt posługi całego Kościoła, uwiarygadniając Jego zbawczą misję.

W nauczaniu św. Jana Pawła II odnajdujemy częste odwołania do ratowania godności każdego człowieka i przywrócenia w nim nadziei na rozwój Bożego życia przez świadczenie mu bezinteresownej posługi miłości poprzez działalność charytatywną w praktyce. Zajmowała ona ważne miejsce w życiu wspomnianego papieża².

* KS. RADOSŁAW BERNARD HERKA SAC - pallotyn, nauczyciel religii w gdańskich szkołach i przedszkolach, kierownik świetlicy środowiskowej „Świetlica u Pallotynów” w Gdańsku, duszpasterz akademicki przy Gdańskim Uniwersytecie Medycznym, rekolekcjonista, autor wielu artykułów z zakresu katechetyki, pedagogiki religii, duchowości chrześcijańskiej, teologii dogmatycznej, publikowanych na łamach pallotyńskiego kwartalnika „Apostoł Miłosierdzia Bożego”.

1 Por. J. Bagrowicz, Towarzyszyć wzrastaniu. Z dyskusji o metodach i środkach edukacji religijnej młodzieży, Toruń 2006, s. 251.

2 Por. W. Przygoda, Posługa charytatywna Kościoła w okresie pontyfikatu Jana Pawła II, „Warszawskie Studia Pastoralne" (2006) nr 4, s. 35-49. 
Papież Benedykt XVI w encyklice Deus Caritas est napisał: „Z upływem lat, wraz ze stopniowym rozprzestrzenianiem się Kościoła, działalność charytatywna utwierdziła się jako jeden $\mathrm{z}$ istotnych sektorów, obok udzielania sakramentów i głoszenia Słowa: praktyka miłości wobec wdów i sierot, wobec więźniów, chorych i wszystkich potrzebujących należy do jego istoty w równej mierze, jak posługa Sakramentów i głoszenie Ewangelii. Kościół nie może zaniedbywać posługi miłości, tak jak nie może zaniedbywać Sakramentów i Słowa" (DCE 22), natomiast w liście apostolskim - Motu proprio Intima Ecclesiae natura (O posłudze miłości), z dnia 11 listopada 2012 roku, zawierającym postanowienia dotyczące organizacji pracy charytatywnej Kościoła zauważa, że działalność na rzecz ubogich i potrzebujących nie powinna ograniczać się tylko do zbierania i rozdzielania dóbr materialnych. Działalność charytatywna Kościoła powinna pełnić przede wszystkim „cenną funkcję pedagogiczną we wspólnocie chrześcijańskiej, wspomagając wychowanie w duchu dzielenia się, szacunku i miłości, zgodnie z logiką Ewangelii Chrystusa” (IEN, Wprowadzenie) ${ }^{3}$.

Wreszcie nauczanie i działanie obecnego papieża Franciszka, który nazywany jest „papieżem ubogich”, stawia ubogich, pokrzywdzonych, zepchniętych na margines życia społecznego, odrzuconych, bezrobotnych i emigrantów w centrum uwagi Kościoła powszechnego. W opublikowanej 24 listopada 2013 roku adhortacji apostolskiej Evangelii Gaudium pisze: „[... ] pragnę Kościoła ubogiego dla ubogich. Oni mogą nas wiele nauczyć. Oprócz uczestnictwa w «sensus fidei», dzięki własnym cierpieniom znają Chrystusa cierpiącego. Jest rzeczą konieczną, abyśmy wszyscy pozwolili się przez nich ewangelizować” (EG 198). Franciszek zaznacza, że nikt nie powinien się czuć wyłączony z troski o ubogich i o sprawiedliwość społeczną (por. EG 58; 205).

\section{Działalność charytatywna w Polsce na przestrzeni wieków}

Pojęcie „charytatywny” oznacza „bezinteresownie pomagający biednym i potrzebującym pomocy"4. Termin ten jest używany w języku polskim zamiennie z pojęciami „dobroczynny” i „filantropijny”. Wywodzące się z kultury antycznej określenie „filantropia” rozumiane jest jako „usposobienie przyjazne ludziom oraz braterska miłość i współczucie wobec bliźniego"s.

Rozwój filantropii, od czasów średniowiecznych, zachodził pod wpływem tradycji chrześcijańskiej. Powstały wówczas dwa nurty - filantropii religijnej (inaczej

\footnotetext{
3 Cytat za http://www.opoka.org.pl/biblioteka/W/WP/benedykt_xvi/motu/intima_ecclesiae_11112012. html (16.08.2014).

4 B. Dunaj, Stownik współczesnego języka polskiego, Warszawa 1996, s. 101.

5 E. Leś, Zarys historii dobroczynności i filantropii w Polsce, Warszawa 2001, s. 17.
} 
dobroczynności) oraz filantropii świeckiej. Z kolei pojęcie „dobroczynność” należy rozumieć jako „niesienie bezinteresownej pomocy w postaci konkretnych działań, datków pieniężnych itp.” ${ }^{\prime}$ Z powyższego wynika, że działalność charytatywna opiera się na jednostkowej chęci pomagania innym ludziom. Korzystając ze skarbca filozofii, na przestrzeni wieków, od starożytności do czasów nam współczesnych, odnajdziemy jeszcze inne pojęcia, które odnoszone są do działalności charytatywnej, takie jak: „altruizm”, „pomoc socjalna” czy „wolontariat””.

Warto zauważyć, że cała działalność charytatywna w obrębie katolicyzmu czerpie ze źródła jakim jest nauczanie Jezusa z Nazaretu i z bogatej Tradycji Kościoła ${ }^{8}$. Chrystus jest przez zjednoczenie natur: boskiej i ludzkiej („unia hipostatyczna") Bogiem i Człowiekiem, w Nim obecna jest pełnia miłości, która emanuje od Jego Ojca w niebie, a którą trzeba określić jako „agape” - miłość transcendentalną ${ }^{9}$. Jednak istnieje również drugi aspekt nauczania i posłannictwa Jezusa, którą sam objawia w Nazarecie, podczas liturgii synagogalnej, odnosząc do siebie tekst z proroka Izajasza: „Duch Pański spoczywa na mnie, ponieważ Mnie namaścił i posłał Mnie, abym ubogim niósł dobrą nowinę, więźniom głosił wolność, a niewidomym przejrzenie, abym uciśnionych odsyłał wolnych [...]" (Łk 4, 16). Jezus otwiera ludzi na potrzeby innych. Od czasów ziemskiego życia Jezusa Chrystusa, następuje dzięki chrześcijanom eksplozja dobroczynności, na niewyobrażalną dotąd skalę. Rozpoczyna się upowszechnianie udzielania pomocy potrzebującym, niezależnie od statusu społecznego, przynależności etnicznej czy kulturowo-obyczajowej, nazywanej „postawą dobrego samarytanina” ${ }^{\prime 0}$.

Kultura dobroczynności kształtowała się w naszym kraju od momentu przyjęcia przez Polskę chrześcijaństwa w 966 roku. Początkowo wzorce czerpano z zachodniej tradycji chrześcijańskiej i stosowanych tam modeli oświatowych oraz sposobu funkcjonowania organizacji charytatywnych. Doświadczenia charytatywne „wieków średnich” bazują na poglądach św. Tomasza z Akwinu, św. Augustyna z Hippony oraz św. Franciszka z Asyżu.

Przez pierwsze lata działalnością charytatywną w Polsce zajmował się jedynie Kościół, bractwa i zakony religijne, mniejsze znaczenie miało wsparcie, zajmujących się polityką oraz dygnitarzy państwa. Kluczowymi instytucjami charytatywnymi

6 B. Dunaj, Stownik..., dz. cyt., s. 176.

7 Por. K. Kabasiński, P. Krakowiak, Filozoficzno-etyczne podstawy altruizmu, w: Podręcznik koordynatora wolontariatu hospicyjnego, red. P. Krakowiak, A. Modlińska, J. Binnebesel, Gdańsk 2008, s. 200.

8 Zarys historyczno-społeczny posługi charytatywnej Kościoła na przestrzeni wieków został szczegółowo omówiony w artykule ks. Bogusława Drożdża pt. Posługa charytatywna znakiem ewangelizacyjnej obecności Kościoła, „Legnickie Studia Teologiczno-Historyczne” (2008) nr 1, s. 48-65.

9 Por. K. Kabasiński, P. Krakowiak, Filozoficzno-etyczne..., dz. cyt., s. 202.

${ }^{10}$ Por. A. Pronzato, Śladami Samarytanina, Kraków 2003, s. 17. 
w średniowieczu były, prowadzone przez różnego rodzaju zakony, zakłady szpitalne i ochronki wznoszone z funduszy fundacji biskupich i darowizn władców. Ważny aspekt działalności charytatywnej wspólnoty chrześcijańskiej stanowiła wówczas oświata kościelna. To właśnie Kościół był pomysłodawcą pierwszych szkół parafialnych i ochronek dla dzieci, które tworzono w większych miastach od drugiej połowy XIV wieku, a od XV wieku również na wsiach, gdzie wychowanie do dobroczynności zajmowało obok zdobywania wiedzy bardzo ważne miejsce ${ }^{11}$.

$\mathrm{W}$ epoce nowożytnej nastąpiła gwałtowna zmiana postaw w stosunku do ludzi ubogich, którzy zaczęli być postrzegani jako zagrożenie dla porządku społecznego. „Chrześcijańskie miłosierdzie wobec wszystkich ubogich uległo zawężeniu do ubogich zasługujących na pomoc, a sami ubodzy zostali podzieleni na godnych i niegodnych wsparcia"12. W pierwszej grupie znalazły się osoby chore i niedołężne oraz dzieci, w drugiej osoby zdolne do wykonywania obowiązków zawodowych. Okres ten cechował się również poszerzeniem zakresu społecznej działalności charytatywnej.

W XVI wieku, pod wpływem reformacji, nastąpiły ważne zmiany w zakresie dobroczynności i filantropii. Doszło do znacznej laicyzacji działalności charytatywnej. Wprowadzona została większa kontrola nad osobami biednymi, w wielu miastach zakazano żebractwa. Próbowano również przekształcić szpitale w podmioty państwowe, utrzymały się one jednak pod zwierzchnictwem Kościoła. Z kolei prywatna działalność charytatywna rozwijała się w charakterze darowizn na cele filantropijne, tworzono także pierwsze fundacje stypendialne na rzecz ludzi młodych, pochodzących $\mathrm{z}$ biednych rodzin.

Na przełomie XVII i XVIII wieku doszło do załamania gospodarczego, które przyczyniło się do wzrostu liczby ludzi ubogich, a tym samym większego zapotrzebowania na pomoc dobroczynną. W tej sytuacji działalność charytatywna opierała się przede wszystkim na aktywności Kościoła katolickiego, przynależących do Niego różnego typu bractw, a także innych istniejących wówczas w Polsce gmin wyznaniowych. Pomoc państwa ograniczała się do współodpowiedzialności za działalność charytatywną Kościoła.

W drugiej połowie XVIII wieku nastąpiła kolejna zmiana w pojmowaniu filantropii - „narzucono dobroczynność, wynikającą z miłości do człowieka [...] zapewnienia opieki prawdziwym ubogim i do wyprowadzenia człowieka ze stanu ubóstwa przez danie mu możliwości pracy, przez wykorzenienie «próżniactwa» i wdrożenie do pracy produkcyjnej, choćby pod przymusem"13.

\footnotetext{
${ }^{11}$ Por. E. Leś, Zarys historii..., dz. cyt., s. 22.

${ }^{12}$ E. Leś, Zarys historii..., dz. cyt., s. 22.

${ }^{13}$ Ch. L. De Montesquieu, O duchu praw, t. II, ks. XXIII, r. XXIX, Warszawa 1957, s. 165.
} 
Wraz z utratą suwerenności na dawnych obszarach Polski zaczęły obowiązywać rozwiązania instytucjonalne działające zgodnie z prawem państw zaborczych. W zaborze pruskim funkcjonował obowiązek opieki publicznej oraz ubezpieczenia od chorób, wypadków w pracy i z tytułu podeszłego wieku. W zaborze austriackim gminy wyznaniowe, $w$ tym wspólnota katolicka, zobowiązane były do udzielania pomocy osobom najuboższym w sytuacjach, gdy zakłady opiekuńcze i instytucje dobroczynne nie posiadały środków na jej udzielenie ${ }^{14}$. Działalność charytatywna najsłabiej rozwinęła się w zaborze rosyjskim, gdzie dobroczynnością zajmowały się głównie organizacje społeczne oraz osoby prywatne.

Dynamiczny rozwój działalności charytatywnej, charakterystyczny dla okresu międzywojennego, skończył się w 1939 roku likwidacją organizacji pomocowych, za wyjątkiem Polskiego Czerwonego Krzyża ${ }^{15}$. W tym okresie pomocy osobom potrzebującym udzielać miała Rada Główna Opiekuńcza. Jednak w rzeczywistości obowiązek ten realizowały grupy charytatywne, działające w obrębie poszczególnych parafii katolickich.

Organizacje dobroczynne wznowiły swoją działalność dopiero po drugiej wojnie światowej. Jednak już w 1952 roku, na mocy dekretu Rady Państwa, wszystkie instytucje charytatywne, posiadające zarządy na terenie kraju, zostały rozwiązane. Dopiero w 1956 roku ich działalność na terenie Polskiej Rzeczpospolitej Ludowej została wznowiona. Skutecznej pomocy, na dużą skalę, udzielały wyłącznie organizacje katolickie, gdyż wszystkie inne stowarzyszenia społeczne były indoktrynowane i nadzorowane przez władze polityczne.

Wraz z wprowadzeniem stanu wojennego w 1981 roku większość organizacji została zlikwidowana, a działalność charytatywną w konspiracji kontynuowała część instytucji społecznych. Pogłębiający się kryzys gospodarczy spowodował spadek poziomu życia obywateli, co zmusiło władze państwa do zaakceptowania tworzących się organizacji katolickich. Warto zaznaczyć, że wówczas Kościół katolicki był największą instytucją świadczącą posługę charytatywną wobec zubożałego społeczeństwa. Dopiero po 1989 roku wznowiły w Polsce swoją działalność zgodnie z prawodawstwem „Caritas” (1o października 1990 roku) jako instytucja dobroczynna Konferencji Episkopatu Polski oraz szereg fundacji na rzecz potrzebujących ${ }^{16}$.

Kolejne ożywienie działalności charytatywnej nastąpiło w późniejszym okresie transformacji demokratycznej. „Zasada pomocniczości znalazła miejsce w ustawie

\footnotetext{
${ }^{14}$ Por. A. Góra, Tradycje Opieki i Pomocy Społecznej w Polsce, „Praca Socjalna” (1989) nr 2, s. 28.

${ }_{15}$ Por. M. Halszka-Kurleto, Organizacje pożytku publicznego. Rozwiązanie prawne, funkcjonowanie, rozwój, Kraków 2008, s. 42.

${ }^{16}$ Patrz: Wstęp do Informatora „Caritas” w Polsce za 2013 r. Razem w Miłości, Warszawa 2013, s. 3.
} 
Z 12 marca 2004 roku o pomocy społecznej, w której zdefiniowano pomoc społeczną jako instytucję polityki państwa oraz w ustawie o działalności pożytku publicznego i o wolontariacie z dnia 24 kwietnia 2003 roku, w której nałożono obowiązek współpracy organów administracji publicznej z organizacjami pozarządowymi w realizacji zadań o charakterze społecznym"17. Kościół w wolnej Polsce dynamizował i poszerzał (czyni to po dziś dzień) swoją działalność charytatywną, zgodnie ze wskazaniami zawartymi w dokumentach II Polskiego Synodu Plenarnego. Są one nieustannie wyznacznikiem i inspiracją dla wspólnot parafialnych i diecezjalnych w Polsce, zgromadzeń zakonnych, stowarzyszeń i instytutów życia apostolskiego oraz wiernych świeckich. Według wspomnianego dokumentu, chrześcijanom w Ojczyźnie trzeba w nowej sytuacji polityczno-ekonomicznej zmierzyć się z nowymi przejawami ludzkiej biedy, rozumianej w aspekcie ekonomicznym (brak żywności i niedostatek materialny), w aspekcie społecznym (izolacja, której przejawem jest samotność), w aspekcie psychologicznym (bezradność) (PSPCh 21), bezrobociem (PSPCh 22), złą kondycją rodzin wielodzietnych (PSPCh 23), zubożeniem emerytów i rencistów (PSPCh 24), sytuacją bezdomnych (PSPCh 26), emigrantów i migrantów (PSPCh 27).

\section{Rodzina, szkoła, Kościół - środowiska dojrzewania młodych do działalności charytatywnej}

Działalność charytatywna Kościoła trwa nieprzerwanie od czasów apostolskich. Wynika z tego, że miłość bliźniego jest „znamieniem prawdziwego ucznia Chrystusowego” (KK 42). Benedykt XVI podkreśla, że „Kościół nigdy nie może być zwolniony od czynienia "caritas» jako uporządkowanej działalności wierzących i, z drugiej strony, nigdy nie będzie takiej sytuacji, w której «caritas» poszczególnych chrześcijan nie będzie potrzebna, gdyż człowiek [...] potrzebuje i zawsze będzie potrzebował miłości” (DCE 29). W związku z powyższym wychowanie dzieci i młodzieży do działalności charytatywnej jest jednym z obowiązków spoczywającym na rodzicach dziecka, wychowawcach, katechetach i duszpasterzach.

Warto na początku jednak zaznaczyć, że w Polsce po 1989 roku trwa nieprzerwanie dyskusja o założenia i kształt pedagogiki socjalnej. Wychowanie do dobroczynności jest motywowane instytucjonalnie albo wynika z głębokich pokładów ludzkiego serca, przynaglanego miłością Chrystusa „Albowiem miłość Chrystusa przynagla nas [...]” (2 Kor, 5, 14). Możemy zauważyć, że do dziś w polskiej

\footnotetext{
${ }^{17}$ Por. M. Halszka-Kurleto, Organizacje pożytku publicznego..., dz. cyt., s. 44.
} 
pedagogice, istnieją nieprzerwanie dwa systemy wychowania młodego pokolenia: liberalno-materialistyczny (trwający w Polsce nieprzerwanie od czasów zniewolenia komunistycznego) oraz chrześcijański. Źródłem pierwszego z nich jest pogląd, który zakłada, że człowiek jest elementem natury i podlega jej odwiecznym prawom. Według tej koncepcji człowiek jest wolny absolutnie i sam może kreować, co jest dobre a co jest złe, co jest prawdziwe a co jest fałszywe. Dowolność interpretacji dotyczy również zasad moralnych, które wynikają z etyki naturalistycznej. Przez subiektywizm w kwestiach wartości i zasad postępowania, wyłania się wszechobecny relatywizm moralny. Wychowanie liberalno-materialistyczne prowadzi do wyeliminowania Boga i zasad Dekalogu z życia osobistego, społecznego i narodowego. W takim wychowaniu zatraca się głębszy sens ludzkiego życia, także w świadczeniu pomocy socjalnej, i utwierdzają się postawy egocentryzmu ${ }^{18}$.

Przeciwwagą dla omówionego systemu jest pedagogika chrześcijańska. Jej źródłem jest pogląd, że człowiek wykracza poza przyrodę. Biorąc pod uwagę uwarunkowania metafizyczne głosi, że jest on bytem, osobą transcendentną ${ }^{19}$, a Jego istotę stanowi nieśmiertelna dusza. Władzami duszy są rozum i wola, które kierują jego postępowaniem. Człowiek dzięki rozumowi poznaje prawdę o niezmiennych, obiektywnych i odwiecznych prawach natury, czyli samego Boga. Natomiast ludzka wola dąży do nieskończonego dobra, którym jest Bóg. W ujęciu pedagogiki chrześcijańskiej, istnieje obiektywny porządek moralny. Człowiek rozeznaje w sumieniu, dzięki łasce, kategorie dokonywanych czynów. Wie, co jest dobre a co jest $\mathrm{zk}^{20}$. Pierwsza ze wspomnianych koncepcji pedagogicznych posiada charakter redukcjonistyczny, kiedy pedagogika chrześcijańska, o charakterze personalistycznym, pozwala na harmonijny rozwój człowieka, doskonalenie jego wewnętrznych sprawności, z których wyniknie jego zaangażowanie w sprawy społeczne, służba na rzecz ludzi ubogich i pokrzywdzonych, w kontekście ostatecznego celu życia człowieka ${ }^{21}$. Kiedy w nurcie pedagogiki liberalno-materialistycznej, autorzy, w odniesieniu do człowieka, posługują się pojęciem ",jednostka”, tak w literaturze chrześcijańskiej zawsze funkcjonują pojęcia „człowiek”, „osoba”, „wychowanek”.

\footnotetext{
${ }^{18}$ Por. B. Śliwerski, Model szkoły w świetle pedagogiki chrześcijańskiej, „Annales. Etyka w życiu gospodarczym" 12 (2009) nr 2, s. 81; Życie i śmierć. Wyzwania działalności charytatywnej, red. J. Stala, Tarnów 2012; Człowiek wobec bólu, cierpienia i śmierci, red. J. Stala, N. Bravená, Kraków 2013.

${ }^{19}$ Por. W. Cichosz, Możliwość dialogu wychowania chrześcijańskiego ze współczesną edukacją polską, Pelplin 2013, s. 129-135.

${ }^{20}$ Por. B. Śliwerski, Model szkoły w świetle pedagogiki..., dz. cyt., s. 81-82.

${ }^{21}$ Podane informacje potrzebują pewnego wyjaśnienia. Otóż autor dla uniknięcia zarzutu stronniczości i braku obiektywizmu naukowego, dokonuje analizy i wykorzystuje w dalszych rozważaniach także literaturę przedmiotu autorów nurtu liberalno-materialistycznego, konfrontując ją z założeniami wychowania chrześcijańskiego i oficjalną nauką Kościoła katolickiego.
} 
Czym jest zatem wychowanie? Wychowanie w wąskim rozumieniu traktowane jest jako „świadome, celowe i specyficzne, pedagogiczne działanie osób z reguły występujących w ich różnych zbiorach (rodzinnych, szkolnych, innych) dokonywane głównie przez słowo (i inne postacie interakcji, zwłaszcza przez przykład osobisty), zmierzające do osiągnięcia względnie trwałych skutków (zmian) w rozwoju fizycznym, umysłowym, społecznym, kulturowym i duchowym jednostki ludzkiej”22. Z kolei wychowanie w szerszym rozumieniu oznacza „oddziaływanie całokształtu specyficznych pedagogicznych bodźców i doświadczeń ogólnospołecznych, grupowych, indywidualnych, profesjonalnych i nieprofesjonalnych przynoszących względnie trwałe skutki w rozwoju jednostki ludzkiej w jej sferze fizycznej, umysłowej, społecznej, kulturowej i duchowej"23. W przypadku pedagogiki chrześcijańskiej mocno w procesie wychowania akcentuje się wychowanie religijne, moralne oraz do konkretnych postaw w społeczeństwie w duchu ewangelicznego „dobrego Samarytanina”.

Współcześnie obowiązek wychowania dzieci i młodzieży spoczywa na domu rodzinnym, najbliższym otoczeniu (szkole, wspólnocie Kościoła) oraz społeczeństwie i jego kulturze ${ }^{24}$. W chrześcijaństwie to rodzina stanowi pierwsze naturalne środowisko wychowawcze (FC 38). Rodzice bądź opiekunowie dziecka w istotny sposób wpływają na jego rozwój, zwłaszcza w sferze moralno-społecznej. Oddziaływanie domu rodzinnego rozpoczyna się bardzo wcześnie, gdy podatność jednostki na recepcję wzorów i wartości jest najwyższa ${ }^{25}$. W dzisiejszych czasach, gdzie stale wzrasta zaangażowanie zawodowe rodziców i niedobór pomocy ze strony dziadków, obserwuje się coraz mniejsze zaangażowanie w wychowanie i niezaspokajanie potrzeb emocjonalnych dzieci. Rozpowszechnia się model wychowania polegający na obciążaniu dzieci dodatkowymi zajęciami i porównywania z lepszymi uczniami. „W kontaktach rodzinnych zanikają normy grzecznościowe, rozluźniają się więzi, brakuje świadomego nauczania wartości”26.

Brak zainteresowania ze strony rodziców powoduje, że dzieci spędzają czas wolny przed telewizorem lub komputerem, co niejednokrotnie ma szkodliwy wpływ na ich zachowanie. Wiele rodzin uważa, że ich zadaniem jest zapewnienie bezpieczeństwa ekonomicznego potomstwu, zaś obowiązek wychowania do konkretnych postaw względem drugiego człowieka spoczywa na pedagogach i środowisku szkolnym. Z kolei wielu pedagogów wychodzi z założenia, że zadaniem

\footnotetext{
${ }^{22}$ W. Pomykało, Encyklopedia pedagogiczna, Warszawa 1993, s. 917.

${ }^{23}$ W. Pomykało, Encyklopedia pedagogiczna..., dz. cyt., s. 918.

${ }^{24}$ I. Koźmińska, E. Olszewska, Z dzieckiem w świat wartości, Warszawa 2007, s. 17.

${ }^{25}$ Por. M. Ogryzko-Wiewiórska, Rodzina w oczach młodego dziecka, w: Rodzina współczesna, red. M. Ziemska, Warszawa 1999, s. 117-119.

${ }^{26}$ I. Koźmińska, E. Olszewska, $Z$ dzieckiem w..., dz. cyt., s. 17.
} 
szkoły jest przede wszystkim edukowanie, nie zaś wychowywanie młodego pokolenia. Szkoła ma jedynie towarzyszyć rodzicom w wychowywaniu dziecka do konkretnych postaw. Jednak zauważalnym staje się dysonans w omawianej przez nas kwestii. Niejednokrotnie szkoła wymaga od dzieci przyswajania obowiązującego materiału lekcyjnego zarazem bagatelizując istotność edukacji w zakresie właściwych norm społecznych. Tego rodzaju postawa podważa autorytet nauczycieli, przyczyniając się do eskalacji agresywnych i wulgarnych zachowań uczniów. Dodatkowo, sytuacja, w której rodzice nie wykazują zainteresowania modelem kształcenia oraz osiągnięciami dziecka, bądź co gorsze, demonstrują lekceważący stosunek do szkoły, wpływa na obniżenie zainteresowania dziecka nauką i samorozwojem.

Liczne badania wskazują, że ogromny wpływ na ogólny rozwój wychowanka, zwłaszcza na sferę moralno-społeczną i intelektualną ma środowisko rodzinne lub opiekuńcze. Mniejsze znaczenie mają „czynniki dydaktyczno-pedagogiczne: programy, treści i metody nauczania w szkole, następnie nauczyciel jako osoba znacząca dla młodych oraz grupy rówieśnicze" ${ }^{27}$. Należy pamiętać, że niedoborów rozwojowych i zaburzeń w funkcjonowaniu wychowanka, pedagodzy nie mogą złagodzić bądź wyeliminować bez nawiązania współpracy ze środowiskiem rodzinnym dziecka.

Z powyższego wynika, że szkoła ma istotny wpływ na wychowanie dziecka przede wszystkim ze względu na długotrwałe oddziaływanie oraz kształtowanie jego osobowości zarówno poprzez przekazywaną wiedzę, jaki i wpajane wartości moralne. Życie szkolne stanowi dla dziecka silny czynnik rozwojowy, w okresie tym wyróżnia się dwie kluczowe fazy. Pierwszy etap obejmuje wiek 7-8 lat dziecka, drugi rozpoczyna się w wieku 9 lat i trwa do 10. roku życia.

W pierwszym etapie pedagog staje się dla dziecka autorytetem, niekiedy większym niż rodzice. Etap ten cechuje rozwój kluczowych funkcji sfery intelektualnej i moralno-społecznej ${ }^{28}$. Brak odpowiednich warunków, które umożliwią wychowankowi opanowanie kluczowych umiejętności negatywnie wpływa na jego dalsze życie.

W drugim etapie zachodzą dalsze zmiany w sferze osobowościowej i intelektualnej dziecka. Charakterystyczne dla tego okresu jest to, że dzieci przestają postrzegać dorosłych jako autorytety, coraz częściej kwestionują ich postawy, opinie i poglądy. Wzrasta znaczenie kontaktów z rówieśnikami, ich akceptacja oraz opinie. Od postawy pedagogów i modelu nauczania zależy jaką będą pełnić rolę w rozwoju intelektualno-moralnym wychowanka.

\footnotetext{
${ }^{27}$ M. Żebrowska, Psychologia rozwojowa dzieci i młodzieży, Warszawa 1982, s. 525.

${ }^{28}$ Por. M. Żebrowska, Psychologia rozwojowa dzieci i młodzieży..., dz. cyt., s. 531.
} 
Zdaniem Barbary Kaji „dziecko i otoczenie oddziaływają na siebie w sposób dwukierunkowy"29. Kontakt jednostki z otoczeniem warunkuje proces jej socjalizacji, który realizuje się w następstwie identyfikacji, naśladownictwa lub modelowania, wpływając na właściwy rozwój społeczny.

Z teorii systemów ekologicznych wynika, że rozwój jednostki stanowi proces obustronnej i progresywnej akomodacji jednostki z otoczeniem. Środowisko społeczne, w którym dziecko funkcjonuje, tworzone jest przez bliskie mu układy nazywane mikrosystemem oraz układy dalsze zwane mezasystemem, makrosystemem i egzosystemem oraz wszelkie zależności pojawiające się miedzy wyżej wymienionymi układami ${ }^{30}$.

W związku z powyższym środowisko rodzinne i szkolne nie jest w stanie zaspokoić wszystkich potrzeb wychowawczych dziecka. Kościół wychodzi naprzeciw potrzebom związanym z uspołecznieniem i kształtowaniem właściwych postaw moralnych dzieci i młodzieży. Pedagogika chrześcijańska w swoich założeniach zakorzenia wychowanka w ponadczasowych wartościach ewangelicznych i ukierunkowuje go na ostateczne przeznaczenie człowieka jakim jest jego zbawienie. Chrześcijańska pedagogia ma na celu doprowadzić wychowanka do pełni człowieczeństwa, wprowadzając go w świat, postrzegany poprzez pryzmat wiary. Rola rodziców chrześcijańskich w procesie wychowania jest nieoceniona ${ }^{31}$. Wypływa ona z zobowiązań jakie narzeczeni zadeklarowali wobec wspólnoty Kościoła podczas udzielania sobie wobec prezbitera sakramentu małżeństwa („Czy chcecie przyjąć i po katolicku wychować potomstwo, którym Was Bóg obdarzy?”). Ich postawa wobec potomstwa od tego momentu staje się posługiwaniem Ewangelii. „Rodzice przy pomocy słowa i przykładu winni być dla swoich dzieci pierwszymi zwiastunami wiary i pielęgnować właściwe każdemu z nich powołanie, ze szczególną zaś troską powołanie duchowe" (KK 11).

Nasilająca się dzisiaj marginalizacja wychowania chrześcijańskiego, zarówno w przestrzeni publicznej, jak i edukacyjnej, powoduje, że Kościół katolicki stoi przed trudnym zadaniem wzbudzenia zainteresowania i chęci uczestnictwa dzieci i młodzieży w pracy charytatywnej. Praca ta ma być podejmowana w duchu miłosierdzia. Celem Kościoła jest przede wszystkim rozwijanie i kształtowanie świata wartości młodych ludzi ${ }^{32}$. Dlatego wychowanie chrześcijańskie akcentuje i opiera się na:

\footnotetext{
${ }^{29}$ B. Kaja, Wspomaganie rozwoju. Psychostymulacja i psychokoekcja, t. VII, Bydgoszcz 1997, s. 9; patrz także P. Pellegrino, Mali dzisiaj. Dorośli jutro Propozycje wychowawcze dla dorastajacych, Warszawa 1995.

${ }^{30}$ Por. U. Bronfenbrenner, Dwa światy wychowania. ZSRR i USA, Warszawa 1988, s. 23.

${ }^{31}$ Patrz W. Cichosz, Pedagogia wiary we współczesnej szkole katolickiej, Warszawa 2010, s. 316-329.

${ }^{32}$ Por. M. Cichosz, Działalność społeczno-wychowawcza Kościoła Katolickiego w środowisku lokalnym na przykładzie miasta Bydgoszcz, Bydgoszcz 1997, s. 83.
} 
- dostosowaniu metod wychowania do obowiązującej kultury;

- tworzeniu treści i celów wychowania w oparciu o nauki Kościoła;

- podporządkowaniu wyników wychowania procesowi wzrastania w chrześcijaństwie ${ }^{33}$.

Wychowanek poprzez przynależność do wspólnoty Kościoła autorytatywnie traktuje zaproponowany mu proces wychowania w duchu Ewangelii. Poprzez swoje życie zmienia otaczający siebie świat, czyniąc go lepszym i bardziej ludzkim. Chrześcijański wychowanek zmienia świat według Ewangelii a nie dostosowuje Ewangelii do wymogów świata.

Zgodnie z zasadami pedagogiki aksjologicznej, fundamentalnym czynnikiem wychowawczym są wartości. Zainteresowanie człowieka wartościami wynika z potrzeby poznawania, posiadania oraz realizowania wartości ${ }^{34}$. Wychowawczym celem Kościoła jest stworzenie takich sytuacji, które umożliwią „obcowanie z wartościami, zdążanie ku wartościom, życie wśród wartości, kontakt uczniów z wartościowymi ludźmi, mających dzięki temu sposobność do krystalizowania swojej wrażliwości aksjologicznej”35. Zdaniem Józefa Kozieleckiego wyróżnia się następujące hierarchie wartości:

- dionizyjską - cechuje ją dążenie jednostki do wygodnego życia, najważniejszą wartością jest konsumpcja różnego rodzaju dóbr;

- heraklesową - charakteryzuje się dążeniem jednostki do władzy i rozgłosu;

- prometejską - odnosi się do altruistycznego i prospołecznego funkcjonowania jednostki;

- apollińską - cechuje ją dążenie jednostki do aktywności twórczej oraz chęć poznawania świata i uczestnictwo w rozwoju nauki i sztuki;

- sokratyczną - charakteryzuje jednostki samodoskonalące się, dla których głównym dobrem jest poznawanie i rozumienie siebie ${ }^{36}$.

Z punktu widzenia pedagogiki chrześcijańskiej, miłosierdzie wobec wszystkich istnień stanowi wartość nadrzędną. Świadczą o tym choćby słowa św. Pawła: „I gdybym rozdał na jałmużnę całą majętność moją, a ciało wystawił na spalenie, lecz miłości bym nie miał, nic bym nie zyskał" (1 Kor 13, 3). Miłość chrześcijańska staje w opozycji do współczesnego rozumienia Miłości. Miłość chrześcijańska jest jasną i bezinteresowną postawą wobec drugiego człowieka, nie zaś, jak dziś próbuje się kreować, tylko namiętnością i uczuciem. Zdaniem Benedykta XVI

\footnotetext{
${ }^{33}$ Por. G. Groppo, Wychowanie chrześcijańskie, w: Słownik katechetyczny, red. J. Gevaert, Warszawa 2007, S. 981-984.

${ }^{34}$ Por. R. Ingarden, Książeczka o człowieku, Kraków 1987, s. 21-25.

${ }^{35}$ U. Ostrowska, Aksjologiczne podstawy wychowania, w: Pedagogika. Podstawy nauk o wychowaniu, red. B. Śliwerski, t. 1, Gdańsk 2006, s. 396-40o.

${ }^{36}$ Por. J. Kozielecki, Koniec wieku nieodpowiedzialności. Eseje humanistyczne, Warszawa 1995, s. $223-225$.
} 
„[...] praktyka miłości wobec wdów i sierot, wobec więźniów, chorych i wszystkich potrzebujących należy do istoty (Kościoła) w równej mierze, jak posługa Sakramentów i głoszenia Ewangelii" (DCE 22). Z kolei ks. Piotr Mazur podkreśla, że "prawdziwa działalność charytatywna wypływa z serca pełnego miłości” ${ }^{37}$.

\section{Wartości moralne fundamentem wychowywania dzieci i młodzieży do działalności charytatywnej}

Zgodnie z wielowiekową nauką Kościoła katolickiego, uczynkami miłosierdzia wobec duszy są: upominanie grzeszących, pouczanie nieumiejętnych, radzenie wątpiącym, pocieszanie strapionych, cierpliwe znoszenie krzywdy, darowanie uraz oraz modlitwa w intencji umarłych i żywych. Uczynki miłosierdzia wobec ciała obejmują: karmienie głodnych, pojenie spragnionych, przyodziewanie nagich, goszczenie podróżnych, pocieszanie więźniów, nawiedzanie chorych oraz grzebanie umarłych (por. KKK 2447).

W celu zachęcenia dzieci i młodzieży do podejmowania działalności charytatywnej należy uczyć ich od samego początku takich wartości jak: szacunek, uczciwość, odpowiedzialność, sprawiedliwość i mądrość. Dzięki posiadaniu tych cnót, wyzwalając się z okowów egoizmu i egocentryzmu, młodzi podejmą radośnie posługę diakonijną wobec innych. Szacunek wobec innych w duchu akceptacji i tolerancji, jest fundamentalną wartością moralną, oznaczającą traktowanie siebie i innych ludzi z godnością. „Godność jest wrodzoną i niezbywalną cechą każdego człowieka, niezależną od jego płci, wieku, kondycji umysłowej czy fizycznej, wykształcenia, stanu posiadania czy pozycji społecznej"38. Od dorosłych oczekuje się zatem przekazywania młodym zdrowej filozofii, opartej na sprawdzonych, klasycznych modelach, wypracowanych przez Greków, Rzymian i chrześcijan. Szacunek zajmuje ważną rolę w kształtowaniu postaw młodych ludzi według klasycznych modeli filozofii chrześcijańskiej, gdzie nadrzędną wartością jest człowiek w odniesieniu do Boga i innych ludzi.

Szacunek wobec dziecka warunkuje jego prawidłowy rozwój emocjonalny oraz stanowi podstawę efektywnego nauczania wartości. Z kolei nieokazywanie szacunku, uniemożliwia wychowankom budowanie szacunku wobec samego siebie, a co za tym idzie, wobec innych ludzi.

\footnotetext{
${ }^{37}$ P. Mazur, Szkolne Koła Caritas szansą wychowania ku wartościom, „Niedziela. Tygodnik katolicki”, Edycja Zamojska (2006) nr 9, s. 12.

${ }^{38}$ I. Koźmińska, E. Olszewska, Z dzieckiem w..., dz. cyt., s. 53.
} 
Czwarte przykazanie Dekalogu głosi "Czcij ojca swego i matkę swoją" (Wj 20, 12), jednak na szacunek ze strony dziecka należy zasłużyć ${ }^{39}$. Dziecko nie nauczy się szacunku w sytuacji, gdy wobec niego wartość ta jest łamana. Co więcej, szacunku nie można nauczyć, stosując presję lub groźby. Właściwa postawa polega na prowadzeniu rozmów na temat szacunku, zadawaniu pytań o rozumienie tego pojęcia oraz wyjaśnianiu jego istoty podczas zajęć szkolnych, na katechezie czy pogadanek $\mathrm{w}$ gronie rodzinnym. Warto $\mathrm{z}$ dzieckiem omówić elementy składowe szacunku (grzeczność, troskę o uczucia i dobro innych, poszanowanie odmienności i godności, honor, podziw i docenienie innych $)^{40}$, ponieważ ułatwi mu to rozumienie sposobów okazywania szacunku w życiu codziennym.

Rodzice, pedagodzy i przewodnicy duchowi powinni być dla młodego pokolenia wzorem uczciwości. Zgodnie z Pismem Świętym, człowiek powinien być uczciwy w mowie i czynie. Dzieci należy wychowywać w taki sposób, aby potrafily być uczciwe wobec siebie i innych, wobec swoich obowiązków oraz spotykających ich w życiu zdarzeń ${ }^{41}$.

Proces wychowania do uczciwości, powinien obejmować konwersacje o konieczności mówienia prawdy (zwłaszcza w kontekście kłamania w dobrych intencjach), poszanowania cudzej własności oraz konsekwencjach wynikających z nieuczciwego postępowania. Ważne jest nauczanie dzieci w taki sposób, aby budowany przez nie system wartości, nie wynikał z trwogi przed karą, lecz stanowił wyraz wewnętrznej potrzeby.

Bardziej złożoną formą uczciwości jest sprawiedliwość. Punktem wyjścia dla sprawiedliwego postępowania jest przekonanie, że wszyscy ludzie mają takie same prawa - „Nie będziesz stronniczym na korzyść ubogiego, ani nie będziesz miał względów dla bogatego. Sprawiedliwie będziesz sądził bliźniego" (Kpł 19, 15).

Ucząc dzieci sprawiedliwości należy wyjaśnić jej społeczny charakter. Wychowanek powinien wiedzieć, że sprawiedliwość odnosi się do interakcji zachodzących między ludźmi, nie dotyczy zaś zjawisk natury czy kolei losu. Skuteczną metodą nauczania sprawiedliwości jest omawianie z dziećmi przejawów społecznej sprawiedliwości i niesprawiedliwości na przykładzie wydarzeń dokonujących się na naszych oczach, przekazywanych drogą szeroko rozumianych mass mediów.

Kolejną wartością moralną, którą należy w dziecku kształtować jest odpowiedzialność za dokonywane wybory, myśli, słowa i czyny ${ }^{42}$, ponieważ „każdy umrze za własne grzechy" (Jr 31, 30). Młode pokolenie powinno wiedzieć, że przestrzeganie

\footnotetext{
${ }^{39}$ Por. J. R. Fugate, Wychowanie dziecka wedtug Pisma Świętego, Lublin 2008, s. 192.

${ }^{40}$ Por. I. Koźmińska, E. Olszewska, $Z$ dzieckiem w..., dz. cyt., s. 56.

${ }^{41}$ Por. I. Koźmińska, E. Olszewska, $Z$ dzieckiem w..., dz. cyt., s. 80.

${ }^{42}$ Por. J. R. Fugate, Wychowanie dziecka..., dz. cyt., s. 183.
} 
wartości moralnych wymaga odpowiedzialności. Ta z kolei narzuca konieczność odwagi, zwłaszcza w sytuacjach, w których młodzi ludzie muszą przeciwstawić się presji grupy rówieśniczej. Przewodnik duchowy powinien wyjaśnić uczniom, że odpowiedzialność, często wymagająca wielu wyrzeczeń, przynosi pozytywne rezultaty.

Mądrość, uznawana od czasów starożytnych za fundament dobrego życia, rozumiana jest jako celowe czynienie dobra w wyniku właściwych wyborów życiowych. „Każda wartość moralna, aby była prawdziwą wartością, a nie bezduszną regułą, która wbrew intencjom może przynieść szkodę i zło, powinna być sprawdzona w zwierciadle mądrości"43.

Wykształcenie w dziecku silnego systemu wartości moralnych umożliwia rozpoczęcie procesu wychowawczego do miłosierdzia, które jest warunkiem koniecznym podejmowania przez nie działalności charytatywnej. Zdaniem Karola Wojtyły miłosierdzie jest „naprzód zasadą czy też ideą, do której ludzie muszą niejako podciągnąć swe postępowanie, jeżeli chcą - czego chcieć powinni - uwolnić je od nastawienia użytkowego, czyli konsumpcyjnego względem innych osób" ${ }^{44}$. W związku z powyższym miłość pozbawiona egoizmu uaktywnia człowieka do czynienia dobra. Przewodnicy duchowi, rodzice oraz pedagodzy mają obowiązek wychowywania (interpersonalnego) dzieci i młodzieży do miłosierdzia.

Zadaniem rodziny jest uczenie dziecka miłości poprzez zaspokajanie jego potrzeb psychicznych i fizycznych, dostarczanie prawidłowych wzorców zachowań oraz budowanie prawidłowego systemu wartości ${ }^{45}$. W procesie wychowywania do działalności charytatywnej nadrzędną rolę odgrywa wychowanie do miłości. Jak zauważa ks. Marek Kluz „Trzeba jednak pamiętać, że jest to zawsze najpierw wychowanie do tego, by człowiek umiał odkryć i przyjąć miłość Boga jako dar, by umiał w duchu dziecięcej ufności przyjąć miłość, którą został obdarowany. A następnie by umiał ten dar w sobie rozwinąć i przekazać innym, by tego daru miłości nie zmarnował" ${ }^{\prime 4}$. Istotne znaczenie w rozwijaniu potrzeby dobroczynności ma zachęcanie dziecka do dzielenia się tym co posiada, odkrywanie zalet u innych oraz odmawianie modlitwy w intencji osób najuboższych, uczestniczeniu w wolontariacie.

Z kolei pedagodzy szkolni oraz członkowie Kościoła pracujący z młodzieżą powinni wprowadzać ją w działalność charytatywną w sposób sukcesywny,

${ }^{43}$ I. Koźmińska, E. Olszewska, Z dzieckiem w..., dz. cyt., s. 212.

${ }^{44}$ K. Wojtyła, Miłość i odpowiedzialność, Lublin 1986, s. 15.

${ }^{45}$ Por. M. Przetacznikowa, Z. Włodarski, Psychologia wychowawcza, Warszawa 1981, s. 44-45.

${ }^{46}$ M. Kluz, Wychowanie chrześcijańskie w rodzinie w dobie permisywizmu moralnego, „Śląskie Studia Historyczno-Teologiczne" (2007) nr 2, s. 370; patrz także W. Cichosz, Wartość rodziny chrześcijańskiej w dobie współczesnych przemian kulturowo-postindustrialnych. Od rodziny nuklearnej do rodziny globalnej, „Studia Włocławskie" (2012) 14, s. 248-266. 
zaczynając od działań dobroczynnych ukierunkowanych na środowiska rówieśnicze ${ }^{47}$. Naturalna w wieku dziecięcym i nastoletnim potrzeba przebywania we własnym gronie aktywizuje chęć pomocy innym.

\section{Czym jest wolontariat?}

Wspominana przez nas już wcześniej ustawa o działalności pożytku publicznego i wolontariacie z 2003 roku, otworzyła przed obywatelami Polski nowe horyzonty realizacji siebie na rzecz potrzebujących w różnych instytucjach, prowadzonych także przez Kościół katolicki na terenie naszego kraju. Odtąd Kościół katolicki stał się obok różnych instytucji o innym światopoglądzie, równouprawnionym partnerem, ale nade wszystko środowiskiem kształtowania ludzi młodych, w oparciu o wzorzec ewangeliczny, poprzez posługę laikatu i duchownych, do pracy charytatywnej.

Dzięki wolontariatowi instytucjonalnemu człowiek, stając blisko ludzkich problemów i potrzeb, zaczynana inaczej postrzegać siebie, swoje wyimaginowane problemy i zaczyna być bezinteresownym darem dla innych. Wolontariuszem nazywamy osobę, która ochoczo i bez wynagrodzenia wykonuje świadczenia na zasadach określonych w ustawie o działalności pożytku publicznego i o wolontariacie. W wolontariat mogą być włączeni wszyscy, bez ograniczeń wiekowych, z tym, że osoby, które nie ukończyły 13 lat, w świetle prawa, nie mogą samodzielnie podjąć decyzji o przystąpieniu do wolontariatu. $\mathrm{W}$ ich imieniu porozumienie może zawrzeć rodzic bądź osoba sprawująca nad nimi opiekę prawną. Dla osób pomiędzy 13. a 18. rokiem życia rodzic bądź opiekun wyraża zgodę na zawarcie porozumienia w sprawie wolontariatu ${ }^{48}$.

\section{Wolontariat chrześcijański}

Na samym początku warto zauważyć, że wielkie dokumenty Soboru Watykańskiego II ani jeden raz nie używają słowa „wolontariat”, to jednak wielokrotnie

\footnotetext{
${ }^{47}$ Por. J. Wal, Formacja charytatywna, http://www.orrk.pl/index.php/kongresy-tematyczne/formacja-duchowa/inspiracje/269-formacja-charytatywna (17.04.2014).

${ }^{48}$ Szerzej na temat przepisów prawnych, dotyczących wolontariatu, praw i obowiązków wolontariusza, patrz L. Pawłowski, Aspekty prawne wolontariatu hospicyjnego, w: Podręcznik koordynatora wolontariatu hospicyjnego, red. P. Krakowiak, A. Modlińska, J. Binnebesel, Gdańsk 2008, s. 237-256.
} 
nakazują chrześcijanom zaangażowanie się w pomoc, w dzieła miłosierdzia i w budowanie społeczeństwa obywatelskiego (KDK 88; DA 19).

Diametralna zmiana następuje w nauczaniu papieża Jana Pawła II. W centrum Jego uwagi zawsze znajduje się wolontariat zainspirowany wartościami ewangelicznymi i nacechowanym humanistyczną wrażliwością. Wolontariat chrześcijański jednak różni się od wolontariatu humanistycznego. Różnica polega na tym, że wolontariat chrześcijański jest kreowany według zasad Ewangelii, ma on teologiczne motywy, jest osadzony w miłości Boga do człowieka i nie wynika tylko ze spontanicznej wrażliwości człowieka na potrzeby bliźniego. Ponadto zawiera w sobie znamiona wszechstronnego rozwoju zarówno wolontariusza jak i osoby, której pomaga, aż do świętości włącznie. Wreszcie wolontariat chrześcijański wiąże się nieodzownie z pogłębioną formacją w duchu Ewangelii i jest jej owocem. Ten wielki papież zauważa w wolontariacie drzemiący potencjał i w nim dopatruje się źródła odnowy społeczno-politycznej oraz cywilizacyjnej świata. Stoi on w opozycji do współczesnej cywilizacji, która charakteryzuje się indywidualizmem, utylitaryzmem oraz hedonizmem. Chrześcijański wolontariat jest świadectwem miłości braterskiej i wierności Ewangelii, i jako taki ma wpływ na przyszłość całej ludzkości ${ }^{49}$. Ojciec Święty Jan Paweł II przypominał, że chrześcijański wolontariusz uczestnicy w misji Kościoła i poprzez swoje zaangażowanie w służbę chorym i biednym, bierze udział w zbawczej misji Kościoła. Wolontariat chrześcijański posiada ponadnaturalny charakter poprzez ewangeliczne zakotwiczenie w osobie Jezusa i w tradycji służby Kościoła wobec potrzebujących. Nie realizuje się jedynie na płaszczyźnie naturalnej niesienia pomocy w potrzebie, ale stara się podnieść miłość do człowieka na wysokość miłości Chrystusa ${ }^{50}$. Do opisania chrześcijańskiego wolontariatu Jan Paweł II używał następujących terminów: dojrzałość, dyskrecja, hojność, szacunek, nadzieja, inicjatywa, ubóstwo, czystość, umiarkowanie, łagodność, poświęcenie, przejrzystość, wiarygodność, chęć dawania, poszanowanie osoby, duchowość, i optymizm ${ }^{51}$. Te cechy powinny definiować każdego wolontariusza - katolika, wychowywanego w tym duchu w łonie Kościoła i dla Kościoła. Odpowiedzialność kształtowania takich dojrzałych postaw spoczywa na rodzicach chrześcijańskich, wychowawcach oraz pasterzach Kościoła. Nikt nie powinien się od nich odżegnywać. Benedykt XVI natomiast podkreślał, że służba wolontariusza jest heroicznym wyrazem chrześcijańskiej miłości i kontynuacją dzieła dobrego Samarytanina. W cytowanej już

\footnotetext{
${ }^{49}$ Jan Paweł II, Przemówienie do młodych, dn. 26.09.1993 r.

${ }^{50}$ Por. D. Giers, Kościół katolicki wobec wolontariatu i posługi wolontariuszy, w: Podręcznik koordynatora wolontariatu hospicyjnego, red. P. Krakowiak, A. Modlińska, J. Binnebesel, Gdańsk 2008, s. 258-259.

${ }^{51}$ D. Giers, Kościół katolicki wobec wolontariatu i posługi wolontariuszy..., dz. cyt., s. 258-259.
} 
encyklice Deus Caritas est czytamy: „Jak pokazuje przykład dobrego Samarytanina z przypowieści, caritas chrześcijańska jest przede wszystkim odpowiedzią na to, co w konkretnej sytuacji stanowi bezpośrednią konieczność: głodni muszą być nasyceni, nadzy odziani, chorzy leczeni z nadzieją na uzdrowienie, więźniowie odwiedzani itd. Organizacje charytatywne Kościoła, począwszy od Caritas (diecezjalnej, narodowej i międzynarodowej) muszą zrobić wszystko, co możliwe, aby były do dyspozycji odpowiednie środki i nade wszystko by byli ludzie, którzy podejmą takie zadania. Gdy chodzi o posługę, jaką ludzie spełniają wobec cierpiących, potrzeba przede wszystkim kompetencji profesjonalnych: niosący pomoc powinni być przygotowani w taki sposób, aby potrafili robić to, co właściwe we właściwy sposób, podejmując wysiłek dalszej troski. Kompetencja zawodowa jest tu pierwszym, podstawowym wymogiem, ale ona sama nie wystarczy. Chodzi bowiem o istoty ludzkie, a osoby ludzkie zawsze potrzebują czegoś więcej niż technicznie poprawnej opieki. Potrzebują człowieczeństwa. Potrzebują serdecznej uwagi. Ci, którzy działają w Instytucjach charytatywnych Kościoła, powinni odznaczać się tym, że nie ograniczają się do sprawnego wypełnienia, co stosowne w danej chwili, ale z sercem poświęcają się na rzecz drugiego, w taki sposób, aby doświadczył on bogactwa ich człowieczeństwa. Dlatego takim pracownikom oprócz przygotowania profesjonalnego potrzeba również, i nade wszystko, «formacji serca»: trzeba ich prowadzić ku takiemu spotkaniu z Bogiem w Chrystusie, które by budziło w nich miłość i otwierało ich serca na drugiego, tak aby miłość bliźniego nie była już dla nich przykazaniem nałożonym niejako z zewnątrz, ale konsekwencją wynikającą z ich wiary, która działa przez miłość (por. Ga 5, 6)" (DCE 31a). Papież Franciszek podczas spotkania z wolontariuszami, posługującymi podczas XXVIII Światowego Dnia Młodzieży w Rio de Janeiro powiedział, że chrześcijański wolontariat przeciwstawia się współczesnej kulturze, promującej to co „przelotne” i wzywał ich do odważnego płynięcia pod prąd $\mathrm{d}^{52}$.

\section{Sprawności wolontariusza chrześcijańskiego}

Praktyczna realizacja przykazania miłości bliźniego w odniesieniu, do każdego napotkanego człowieka, bez względu na kolor skóry, przekonania, język, wyznawany światopogląd stanowią fundament posługi chrześcijańskiego wolontariusza. Każdy wolontariusz, ukształtowany przez wspólnoty kościelne, koordynatorów

\footnotetext{
${ }^{52}$ Więcej na temat papieża Franciszka i Jego odniesień do wolontariatu i wolontariuszy w artykule P. Krakowiaka pt. Edukacyjne funkcje wolontariatu i ich percepcja w nauczaniu Kościoła w XXI w., „Paedagogia Christiana" (2013) nr 2, s. 179-182.
} 
i przewodników duchowych, działający z potrzeby serca, przynaglany wartościami i cnotami chrześcijańskimi, uwrażliwia siebie oraz swoje otoczenie na każdy przejaw ludzkiej nędzy. Chcąc przedłużać posługę miłości Jezusa na ziemi, nieustannie rozeznaje „znaki czasu” oraz konkretne potrzeby w najbliższym otoczeniu, w szkole, domu rodzinnym, sąsiedztwie oraz z racji wyznawanej wiary bezinteresownie organizuje pomoc. Nieustannie pogłębia swoją więź z Jezusem poprzez zdobywanie wiedzy religijnej, poprzez uczestniczenie w praktykach religijnych, rekolekcjach i innych formach doskonalenia proponowanych przez Kościół. Formacja dzieci i młodzieży do działalności wolontariackiej podejmowana w ramach działalności wspólnot parafialnych, szkolnych grup charytatywnych, duszpasterstwa akademickiego, przynoszą dla Kościoła, ale również dla całego społeczeństwa, w którym Kościół się uobecnia, nieocenione korzyści wychowawcze, przyczyniając się do zwalczania w nich postaw egoistyczno-hedonistycznych, marazmu życiowego i bezideowości. Przyczynia się nade wszystko do rozwoju ich osobowości na drodze formacji ludzkiej, intelektualnej, duchowej i moralnej. Zaangażowanie na rzecz potrzebujących wyzwala w młodych poczucie odpowiedzialności za los innych, poszanowania czyjegoś i swojego czasu, wykorzystana swoich talentów, zdolności dla tych, którzy od losu nie otrzymali tego, co posiada wolontariusz ${ }^{53}$. Dzięki zaangażowaniu w duchu chrześcijańskim, młodzi ludzie lepiej przeżywają swoją eklezjalność, która dziś często kojarzona jest z pustą indoktrynacją. Dzięki działalności charytatywnej i świadectwie innych wolontariuszy, wiara konkretnych osób staje się bardziej dojrzałą i żywą. Należy jednak pamiętać, że dla chrześcijanina troska o drugiego człowieka nie zaczyna się od wzmożonej aktywności społecznej, ale „urzeczywistnia się najpierw w podjęciu zadań, za które ponosi się odpowiedzialność osobistą; człowiek uczestniczący w dobru społeczności przez troskę o wychowanie w swojej rodzinie i przez sumienność w pracy" (KKK 1912). Nie jest zgodny z duchem Ewangelii taki wolontariat, który uderza w podstawowe obowiązki wolontariusza wynikające $\mathrm{z}$ jego powołania. Należy zwrócić uwagę, aby w wychowywaniu dzieci i młodzieży do wolontariatu, nie stał się on formą alienacji i ucieczki od realiów życia czy też prawdy o sobie samym. Praca charytatywna nie może stać na przeszkodzie młodemu człowiekowi na drodze do jego rozwoju. Zaangażowanie w wolontariat chrześcijański powinno wynikać z głębokiej formacji i być jej owocem. Dlatego na koniec jeszcze raz mocno należy podkreślić potrzebę kształtowania sprawności duchowych wolontariusza katolickiego poprzez: kierownictwo duchowe, życie sakramentalne i uczestniczenie w grupach formacyjnych. Wolontariat katolicki nie jest tylko

\footnotetext{
${ }^{53}$ Por. P. Krakowiak, Wolontariat w opiece u kresu życia, Toruń 2013, s. 178.
} 
ofiarowaniem bliźniemu swojego czasu, sił i umiejętności, ale także dzieleniem się motywami życia i nadziei (por. KDK 31).

\section{Zakończenie}

W życiu Kościoła nadrzędną rolę obok działalności kerygmatycznej, liturgicznej, koinonijnej zajmuje posługa diakonijna. Wychowanie do dobroduszności i dobroczynności wszystkich członków Kościoła, także dzieci i młodzieży, przyczynia się do tego, że nasz świat jest coraz bliższy idei Królestwa Bożego, zapowiadanego przez Jezusa z Nazaretu, „który przyszedł, aby służyć [...]” (Mk 45).

W chrześcijaństwie nadrzędną rolę odgrywa, i do końca będzie ogrywać, służebna Miłość wobec każdego stworzenia, dlatego potrzeba nieustannego wprowadzania do przestrzeni wychowawczej młodego pokolenia, idei wolontariatu, bezinteresownego daru $\mathrm{z}$ siebie, na rzecz ludzi potrzebujących i odrzuconych w duchu chrześcijańskim. Jednomyślność i jednotorowość środowisk kształtujących młode pokolenie: rodziny, szkoły oraz wspólnoty Kościoła (na różnym szczeblu) w tej kwestii, jest dziś bardzo potrzebna, ponieważ przyczyni się do tego, że wokół nas będzie więcej widocznego dobra i sprawiedliwości.

\section{Proponowana literatura}

Bagrowicz J., Towarzyszyć wzrastaniu. $Z$ dyskusji o metodach $i$ środkach edukacji religijnej młodzieży, Toruń 2006.

Bronfenbrenner U., Dwa światy wychowania. ZSRR i USA, Warszawa 1988.

Cichosz M., Działalność społeczno-wychowawcza Kościoła Katolickiego w środowisku lokalnym na przykładzie miasta Bydgoszcz, Bydgoszcz 1997.

Cichosz W., Możliwość dialogu wychowania chrześcijańskiego ze wspótczesna edukacja polską, Pelplin 2013.

Cichosz W., Pedagogia wiary we wspótczesnej szkole katolickiej, Warszawa 2010.

Cichosz W., Wartość rodziny chrześcijańskiej w dobie wspótczesnych przemian kulturowo-postindustrialnych. Od rodziny nuklearnej do rodziny globalnej, „Studia Włocławskie" (2012) 14, s. 248-266.

Człowiek wobec bólu, cierpienia i śmierci, red. J. Stala, N. Bravená, Kraków 2013.

De Montesquieu Ch. L., O duchu praw, t. II, ks. XXIII, r. XXIX, Warszawa 1957.

Drożdż B., Postuga charytatywna znakiem ewangelizacyjnej obecności Kościoła, „Legnickie Studia Teologiczno-Historyczne” (2008) nr 1, s. 48-65.

Dunaj B., Stownik współczesnego języka polskiego, Warszawa 1996. 
Fugate J. R., Wychowanie dziecka według Pisma Świętego, Lublin 2008.

Giers D., Kościół katolicki wobec wolontariatu i posługi wolontariuszy, w: Podręcznik koordynatora wolontariatu hospicyjnego, red. P. Krakowiak, A. Modlińska, J. Binnebesel, Gdańsk 2008, s. 257-273.

Góra A. W., Tradycje Opieki i Pomocy Społecznej w Polsce, „Praca Socjalna” (1989) nr 2, s. $28-30$.

Groppo G., Wychowanie chrześcijańskie, w: Słownik katechetyczny, red. J. Gevaert, Warszawa 2007, s. 981-984.

Halszka-Kurleto M., Organizacje pożytku publicznego. Rozwiązanie prawne, funkcjonowanie, rozwój, Kraków 2008.

Informator Caritas w Polsce za 2013 r. Razem w Miłości, Warszawa 2013.

Ingarden R., Książeczka o człowieku, Kraków 1987.

Kabasiński K., Krakowiak P., Filozoficzno-etyczne podstawy altruizmu, w: Podręcznik koordynatora wolontariatu hospicyjnego, red. P. Krakowiak, A. Modlińska, J. Binnebesel, Gdańsk 2008, s. 200-213.

Kluz M., Wychowanie chrześcijańskie w rodzinie w dobie permisywizmu moralnego, „Śląskie Studia Historyczno-Teologiczne" (2007) nr 2, s. 364-374.

Kozielecki J., Koniec wieku nieodpowiedzialności. Eseje humanistyczne, Warszawa 1995.

Koźmińska I., Olszewska E., Z dzieckiem w świat wartości, Warszawa 2007.

Krakowiak P., Edukacyjne funkcje wolontariatu i ich percepcja w nauczaniu Kościoła w XXI w., „Paedagogia Christiana” (2013) nr 2, s. 163-184.

Krakowiak P., Wolontariat w opiece u kresu życia, Toruń 2013.

Leś E., Zarys historii dobroczynności i filantropii w Polsce, Warszawa 2001.

Mazur P., Szkolne Koła Caritas szansą wychowania ku wartościom, „Niedziela. Tygodnik katolicki”, Edycja Zamojska (2006) nr 9, s. 12-13.

Ogryzko-Wiewiórska M., Rodzina w oczach młodego dziecka, w: Rodzina współczesna, red. M. Ziemska, Warszawa 1999, s. 117-119.

Ostrowska U., Aksjologiczne podstawy wychowania, w: Pedagogika. Podstawy nauk o wychowaniu, red. B. Śliwerski, t. 1, Gdańsk 2006, s. 396-400.

Pawłowski L., Aspekty prawne wolontariatu hospicyjnego, w: Podręcznik koordynatora wolontariatu hospicyjnego, red. P. Krakowiak, A. Modlińska, J. Binnebesel, Gdańsk 2008, s. 237-256.

Pellegrini P., Mali dzisiaj. Dorośli jutro. Propozycje wychowawcze dla dorastających, Warszawa 1995.

Pomykało W., Encyklopedia pedagogiczna, Warszawa 1993.

Pronzato A., Śladami Samarytanina, Kraków 2003.

Przetacznikowa M., Włodarski Z., Psychologia wychowawcza, Warszawa 1981.

Przygoda W., Posługa charytatywna Kościoła w okresie pontyfikatu Jana Pawła II, „Warszawskie Studia Pastoralne" (2006) nr 4, s. 35-49. 
Rusiecka A., Rola rodziny w kształtowaniu wartości kulturalnych dziecka, Słupsk 2003. Śliwerski B., Model szkoły w świetle pedagogiki chrześcijańskiej, „Annales. Etyka w życiu gospodarczym" 12 (2009) $\mathrm{nr}$ 2, s. 77-89.

Wal J., Formacja charytatywna, http://www.orrk.pl/index.php/kongresy - tematyczne/ formacja-duchowa/inspiracje/269-formacja-charytatywna (17.04.2014).

Wojtyła K., Miłość i odpowiedzialność, Lublin 1986.

Wspomaganie rozwoju. Psychostymulacja i psychokoekcja, t. VII, red. B. Kaja, Bydgoszcz 1997.

Żebrowska M., Psychologia rozwojowa dzieci i młodzieży, Warszawa 1982.

Życie i śmierć. Wyzwania działalności charytatywnej, red. J. Stala, Tarnów 2012. 